\title{
O PIONEIRO SÍLVIO BERTO: FOTOGRAFIA E SOCIABILIDADE
}

Jordão Horta Nunes*

\section{Resumo}

O artigo analisa a atividade profissional de Sílvio Berto, fotógrafo pioneiro em Goiânia, com base numa concepção pragmática do ato fotográfico. O significado de suas obras, em quaisquer dos principais gêneros que desenvolveu ("reportagem social", vistas urbanas e fotodocumentação), relaciona-se com a interatividade social em situações de produção e recepção das fotos de estúdio. Participante dos círculos de sociabilidade na capital emergente, Berto construía uma identidade profissional que assimilava, por um lado, elementos do discurso da modernidade que formava o imaginário de Goiânia, mas recuperava, por outro lado, atitudes e valores dos pintores retratistas, além de características da fotografia de "reportagem social” praticada no Brasil desde o início do século XX.

Palavras-chave: Ato fotográfico, “reportagem social”, sociabilidade.

Quem observar os movimentos de um fotógrafo munido de um aparelho (ou de um aparelho munido de fotógrafo) estará observando movimento de caça. $\mathrm{O}$ antiqüíssimo gesto do caçador paleolítico que persegue a caça na tundra. Com a diferença de que o fotógrafo não se movimenta em pradaria aberta, mas na floresta densa da cultura. Seu gesto é, pois, estruturado por essa taiga artificial, e toda fenomenologia do gesto fotográfico deve levar em consideração os obstáculos contra os quais o gesto se choca: reconstituir a condição cultural do gesto.

(VILÉm Flusser, A filosofia da caixa preta)

* Professor de Sociologia da UFG.

E-mail: jordao@fchf.ufg.br 
A metáfora do fotógrafo como caçador (FLusser, 1985 [1983]; ZunZunEGUI, 1992; SonTAG, 1981 [1973]) é perfeita para expressar a concepção pragmática que orienta o estudo que aqui desenvolvemos da atividade profissional de Sílvio Berto, um dos pioneiros da fotografia em Goiânia. As visões da fotografia como um análogo ou espelho da realidade (postura idealista), ou como traço visível da realidade (postura realista), relegaram a imagem fotográfica a um papel epistemológico secundário, mera ilustração de eventos ou pessoas, na história e nas ciências sociais. A concepção pragmática do gesto ou ato fotográfico, questionando a distinção entre realismo e idealismo, integra as duas perspectivas anteriores. Nosso ponto de partida não é o objeto fotográfico, mas o ato que o constitui como tal; investigar um ato fotográfico consiste em desvelar as condições culturais e sociais que possibilitam a sua "gênese", que, nas palavras de Dubois (1998 [1990], p. 59) "pode ser tanto um ato de produção propriamente dito (a "tomada") quanto um ato de recepção ou de difusão". A teoria da fotografia como imagem-ato, defendida por Philippe Dubois, contesta a idéia de que o objeto fotográfico se caracteriza por similaridade ou analogia com a realidade sensível à percepção visual.

A compreensão do enfoque metodológico e dos objetivos neste estudo requer um esclarecimento, ainda que sumário, dessa perspectiva pragmática da análise fotográfica, orientada a partir da semiótica de Charles Sanders Peirce.

O significado da fotografia é considerado aqui como um objeto da semiótica geral dos signos. A semiótica da imagem, como estudo de um signo diferente dos sons ou das palavras, é um problema epistemológico recente e polêmico, que não nos interessa aqui. ${ }^{1} \mathrm{~A}$ pragmática da fotografia tem sua base na semiótica triádica de Peirce, proposta como uma teoria geral dos signos e tendo o estudo da imagem fotográfica apenas como uma de suas possíveis aplicações. O estudo dos signos é necessário, para Peirce (1958 [1931-1935], 2281), pois “todo raciocínio é uma interpretação de signos de algum tipo”; há, portanto, uma relação estreita entre lógica e semiótica em sua filosofia da representação. Os elementos característicos de uma representação são relacionados numa tríade fundamental: o signo (aquilo que se coloca no lugar de algo para alguém, sob alguma forma ou capacidade e que deve ter êxito em fazer com que alguém apreenda seu objeto), o objeto (aquilo a que o signo se 
refere) e o interpretante (um signo mais desenvolvido, que tem o mesmo objeto e é engendrado na mente pelo signo; um interpretante se torna o signo para um futuro interpretante, numa série infinita). Suponhamos, como exemplo, a foto de uma praça de Goiânia. A imagem fotográfica é um signo, que tem como objeto uma vista urbana. Pode gerar um pensamento como “É uma praça pública numa cidade”, como interpretante para alguém que não conheça Goiânia, ou não consiga identificar a praça fotografada. Esse pensamento pode estimular uma série de outros interpretantes, como o proferimento "É a Praça Cívica, na década de 50”, a interjeição “Que vista linda!”. Cada interpretante se torna um sinal para outros interpretantes derivados, numa seqüência potencialmente infinita, processo que recebeu, na interpretação de Umberto Eco (1991 [1984], p. 111) a qualificação de “semiose ilimitada”. Uma interpretação bem-sucedida ocorre quando reduzimos a imagem a outros signos, do mesmo sistema semiótico ou de outros sistemas, de modo que o interpretante, além de traduzir o objeto interpretado sob algum aspecto, nos faça conhecer alguma coisa a mais do interpretado. Peirce desenvolve, em sua lógica, a tríade fundamental signo-objeto-interpretante, analisando-a segundo as relações signo-objeto, signo-interpretante e objeto-interpretante, interpretadas em conjunção com as categorias fenomenológicas (primeiridade, secundidade e terceiridade) e com as categorias metafísicas (possibilidade, realidade e destino). Cada uma dessas relações origina uma tríade derivada, das quais a mais importante decorre da relação entre o signo e seu objeto; nessa tricotomia o signo é um ícone, um índice ou um símbolo (PEIRCE, 1958 [1931-1935], 2.247).

O ícone relaciona-se com seu objeto por similaridade em algum aspecto, e essa relação de similaridade é a base da capacidade que o signo tem de tomar esse objeto como referência. Uma foto é, assim, um signo icônico, quando considerada no aspecto de sua similaridade com um objeto do mundo real ou, mais propriamente, de sua similaridade com a realidade sensível à percepção visual. $\mathrm{O}$ índice mostra algo sobre as coisas, em virtude de uma contigüidade física com elas; o exemplo prototípico de um signo indicial é uma placa de trânsito indicando uma direção a tomar, ou um pronome relativo colocado após o nome da coisa a que se pretende remeter. A concepção da fotografia como signo indicial está presente na idéia de que a foto seja um traço do real (BAzIN, 1947); 
em outros termos, a especificidade ontológica da fotografia, em relação a outras imagens, está num tipo de correspondência com a natureza, o qual é determinado muito mais pelo processo químico de fixação no suporte do que pelo dispositivo ótico de captação (câmera obscura, lentes, diafragma etc.). Contudo, essa concepção indicial da fotografia como traço físico da realidade não é a que privilegiamos neste estudo. Não há um privilégio epistemológico da gênese do processo, uma procura pelo “ato originário”, mas uma valorização do ato fotográfico numa perspectiva mais ampla, abarcando tanto o dispositivo técnico e o enfoque até o momento da recepção, abrangendo, "por uma extensão progressiva, do conjunto dos dados que definem, em todos os níveis, a relação desta com sua situação referencial” (Dubois, 1998 [1990], p. 66. Grifos do autor). Finalmente, o signo é simbólico quando seu uso é mediado por um contrato ou convenção. Sua aplicação prototípica é qualquer palavra comum num sistema lingüístico. O símbolo é aplicável a qualquer coisa que possamos encontrar para realizar a idéia conectada com a palavra, embora não identifique essa coisa. "Ele não nos mostra um pássaro, nem representa diante de nós uma doação ou um casamento, mas supõe que sejamos capazes de imaginar essas coisas e que associemos a palavra com elas”. O aspecto da fotografia como signo simbólico fica evidente, por exemplo, em fotos publicitárias empregando locais, personagens ou situações socialmente reconhecidos e vinculando-os a determinados objetos ou práticas.

Os signos icônico, indicial e simbólico não se apresentam na forma pura nem são mutuamente exclusivos. São perspectivas na interpretação do objeto, que podem ser articuladas de forma variada, conforme a situação, o contexto ou a fase da realização do ato fotográfico. Partimos da hipótese de que a concepção da fotografia como índice é mais frutífera para a análise da obra fotográfica de Sílvio Berto, em relação às perspectivas icônica e simbólica. Nossa atenção se dirige, assim, para as razões e motivos que orientam as ações de um fotógrafo pioneiro em Goiânia, cidade planejada e construída no surto desenvolvimentista e expansionista que distinguiu a política econômica no Estado Novo. Os indícios que identificam e constituem suas fotografias relacionam-se, por um lado, com as condições de trabalho dos fotógrafos de estúdio na primeira metade do século XX no Brasil, com as exigências 
técnicas da produção fotográfica na época e com o imaginário social que envolve a distribuição e a recepção dos signos fotográficos. Por outro lado, tais indícios são ligados à história de vida e a fatores subjetivos, o que não implica considerá-los de natureza individual. As dimensões objetiva e subjetiva do tipo de ação que estamos considerando se integram no que poderíamos chamar de consciência prática, ou até mesmo de sentido ou conhecimento prático, que compreende as regras da vida comum.

A literatura sociológica tem registrado, nas últimas décadas, o interesse pela problemática do conhecimento prático na teoria da ação, como evidenciam as freqüentes referências ao conceito de habitus, de Pierre Bourdieu. Trata-se de um sistema de disposições duráveis e transferíveis que integra experiências passadas e funciona como uma “matriz de percepções, apreciações e ações” (Bourdieu, 1983 [1972]), possibilitando, por extensão analógica, a realização de empreendimentos infinitamente variados e permitindo a solução de problemas estruturados de forma similar. Tomamos o conceito de habitus como orientação metodológica para a compreensão da ação de fotografar na prática profissional de Sílvio Berto, ainda que essa atitude não configure uma adesão aos pressupostos teóricos, em maior nível de abstração, que o autor sustenta em sua teoria da prática social. Outras teorias sociológicas que procuram integrar as dimensões da agência e da estrutura ${ }^{2}$ não seriam incompatíveis, segundo nos parece, com a característica fundamental do habitus, ou seja, a de constituir uma estrutura estruturada predestinada a operar como estrutura estruturante, ou, em outras palavras, de constituir uma estrutura, enraizada na experiência prática, com disposição normativa. Há uma conseqüência técnica imediatamente decorrente do privilégio epistemológico da disposição do habitus em nossa investigação, que é a valorização do discurso e das representações empregadas por fotógrafos profissionais. Os indícios desse quadro da percepção e da experiência centrado no ato de fotografar serão extraídos de entrevistas dadas por Sílvio Berto, por seus familiares, amigos e colegas de profissão, anúncios e matérias de jornais de época; ${ }^{3}$ recorremos eventualmente à história da fotografia no Brasil e no mundo, bem como a estudos sociológicos específicos com base na fotodocumentação. 


\section{O início da carreira e a chegada a Goiânia ${ }^{4}$}

Berto nasceu na Itália em 1908 e veio para o Brasil com os pais, por volta de 1913. A família se dedicou à agricultura cafeeira no interior de São Paulo. Iniciou seu aprendizado na arte da fotografia aos 13 anos, como discípulo do mestre Comparini, um artista italiano que morava na cidade de Matão. Seguiu, anos mais tarde, para São Paulo; iniciou sua vida profissional nos cinemas Paramount e Santa Helena, desenhando e montando diapositivos na propaganda cinematográfica. Trabalhou também como auxiliar em estúdios fotográficos, até montar seu próprio estúdio na Praça da Sé. Embora tenha conseguido, nesse período, sucesso econômico e profissional, Berto deixou São Paulo em 1934, para viajar por outras regiões do país, movido por um espírito aventureiro e fugindo da concorrência que se tornara acirrada. Sílvio Berto trabalhou em Minas Gerais, Goiás e Mato Grosso, de 1934 a 1936; construiu bons relacionamentos e realizou diversos trabalhos profissionais, como os álbuns com dados estatísticos e fotografias para as cidades de Catalão e Rio Verde, além da primeira edição de cartões postais em Uberlândia. Finalmente, fixou-se em Campinas (hoje bairro de Goiânia) em junho de 1936 e passou a organizar e dirigir o Cine Campinas, única casa de diversões na época, local de exibição de filmes e de apresentações teatrais e musicais.

Sílvio Berto montou seu primeiro estúdio fotográfico próximo à Praça Joaquim Lúcio, ainda em Campinas. Em 1942, já casado com Dona Marta, transferiu o Foto Berto para a Avenida Araguaia, quase esquina com a Av. Anhanguera, no centro de Goiânia. Era um estúdio maior e mais bem equipado: vitrines artisticamente montadas, com retratos das pessoas mais ilustres da cidade; salão com cortinas, cenários pintados à mão, refletores de luz, câmaras fotográficas de madeira sobre tripés articulados compunham um ambiente moderno e atraente para a época. Sílvio Berto era muito elogiado por seu trabalho no estúdio: cuidadoso na iluminação e perfeccionista no retoque das chapas de vidro, conferia um acabamento criativo e primoroso a suas fotografias. O reconhecimento demonstrado por seus clientes por seu trabalho parecia refletir a imagem profissional que o próprio Berto construía, identificando-se como um fotógrafo de estúdio. Justificando sua saída de São Paulo, Berto, em 
entrevista concedida em 1983, dizia vislumbrar melhor possibilidade financeira viajando e levando seu trabalho para cidades menores: "como fotógrafo de estúdio, pois nunca fui de reportagem”.

O trabalho fotográfico de Berto não se resumia a fotos de estúdio; podemos classificar sua produção em três categorias gerais: "reportagem social”, vistas e fotodocumentação. Contudo, demonstraremos, a seguir, que sua identificação com o estúdio seria determinante na técnica e no estilo desenvolvidos na produção de outros tipos de fotografia. Há razões sociais, além de fatores técnicos ou estéticos, que justificam o apego de Berto ao trabalho no estúdio: o Foto Berto constituía uma extensão das formas de sociabilidade de que o fotógrafo participava ativamente na Goiânia emergente dos anos 40.

\section{Foto Berto: interação e sociabilidade}

Goiânia, a exemplo de Belo Horizonte no início do século XX, foi construída como efetivação de uma atitude política do governo estadual para mudança da capital, promovendo e executando o planejamento urbano. Contudo, há que se diferenciar o discurso da modernização, ligado a propósitos políticos, motivações estéticas ou ao imaginário simbólico, das práticas sociais e culturais, ou, em outras palavras, da experiência social. O discurso mudancista, calcado na idéia de trazer a modernidade a Goiás, implicando a emergência política de novos grupos e a derrocada de antigos grupos até então dominantes, esbarrava em obstáculos consideráveis. O desafio era construir - com base num plano urbanístico racionalista, que acolhia inovações estéticas e levava em conta as condições geográficas e climáticas do Estado - uma cidade em região distante dos centros de decisão política, que seria ocupada por uma sociedade já diferenciada cultural e economicamente, mesmo nas fases iniciais de seu desenvolvimento. ${ }^{5}$ A cidade ostentava, no início de seu desenvolvimento, a despeito de aura construída em torno da modernidade, o feitio de uma pequena cidade do interior no aspecto social e cultural; Goiânia, de 1933 até a década de 50, ainda que simbolizasse os atributos e um ideal da modernidade, estava longe de materializá-los na experiência das relações sociais. Baseando-se em diversas leituras da modernidade 
no Brasil, Genilda D’Arc Bernardes (1998, p. 51) analisa a ocorrência da modernidade em Goiás e reconhece que

o projeto moderno da cidade de Goiânia e o próprio significado do conceito de "novo" para Goiás, à época, vincula-se muito mais à concepção de receptor do que à de produtor da cultura da modernidade.

Os depoimentos dos pioneiros são exemplares na distinção entre o discurso mudancista e a experiência social no período. ${ }^{6}$ No entanto, está fora de nosso alcance reconstruir a vida social em Goiânia nessa época; o importante é destacar o caráter provinciano da cidade em formação, caracterizando as relações de sociabilidade.

Eliézer de Oliveira (1999, p. 29-69) caracteriza a dimensão provinciana da Goiânia emergente, ressaltando principalmente a influência de Campinas, núcleo urbano já centenário, sobre a nova capital. Ainda que houvesse uma rivalidade natural entre dois núcleos urbanos, um tradicional, outro aspirante à modernidade, era inegável a dependência mútua entre ambos em vários aspectos. Campinas experimentou um surto de crescimento e desenvolvimento (principalmente no comércio) com as obras da cidade planejada; Goiânia, por outro lado, dependia daquele lugarejo antigo e de sua estrutura urbana, embora precária, para atendimento de diversas necessidades, inclusive no aspecto do lazer. Outro argumento para afirmar que a ligação entre Campinas e a Goiânia emergente tinha caráter tradicional e provinciano era a procedência da elite de Goiânia. Os novos grupos eram formadas por famílias tradicionais de Goiás, Rio Verde, Anápolis, Pires do Rio, Catalão e outras cidades goianas e apresentavam nível socioeconômico semelhante. Segundo Oliveira (1999, p. 45) "uma das principais preocupações das famílias pioneiras era desenvolver espaços para a integração social, escassos na nova Capital, naquele tempo”. Assim, eram realizados eventos interativos, como os saraus musicais, as festas e bailes de réveillon no Palácio das Esmeraldas, para os quais era convidada a elite local. Surgiram também espaços institucionalizados, como o Automóvel Clube, inaugurado em 1940, primeiro clube social de Goiânia, que se transformou no Jóquei Clube de Goiás, a partir de 1942. 
Tais tipos de encontros ou instituições constituíam momentos de efetivação da sociabilidade, no sentido bem próximo ao conferido por Simmel (1983 [1950]) ao termo. Para o sociólogo alemão, a sociabilidade é a forma do jogo da sociação, esta consistindo num "processo em que os fluxos da experiência vivida ganham forma e persistem para além dos conteúdos íntimos originais” (СонN, 1998, p. 55). A forma social da sociabilidade teve um momento de realização privilegiado nos salões em Berlim do século XIX - caracterizados, pela espontaneidade, num espaço de conversação, onde os indivíduos, em situação de igualdade, falavam sobre temas literários, artísticos ou políticos.

A sociabilidade depende de uma auto-regulação dos indivíduos em suas relações com os outros, feita por meio do sentimento do tato e da discrição; trata-se de uma arte que se efetiva na forma de um jogo de aproximações e afastamentos. Tal controle interno, que não é explicado por meio de estratégias de comportamento ou de ação em sua realização empírica, só se realiza numa estrutura social ideal para a manifestação da cultura subjetiva, sem hierarquia de méritos ou de status, ou seja, uma “estrutura democrática”. Essa condição estrutural não existe naturalmente, deve ser construída no interior de uma única camada social; por isso, a sociabilidade só se efetiva em ambientes em que se torna possível o jogo da interação livre da competição econômica. Os eventos interativos (saraus, festas no Palácio, reuniões), assim como os primeiros clubes sociais na Goiânia emergente, constituíram ambientes adequados para a efetivação da forma da sociabilidade, que constitui também a forma de interação entre grupos pequenos, típica de cidades tradicionais do interior.

O início da vida profissional de Sílvio Berto em Campinas não se deu pela prática profissional da fotografia, mas por contatos feitos em redes de sociabilidade, que o conduziram a desempenhar outras ocupações. Quando saiu de São Paulo, Berto trabalhou em Minas Gerais, Goiás e Mato Grosso, de 1934 a 1936, registrando com sua câmara fotográfica, de madeira e fole, pessoas e lugares nunca antes fotografados. Nesse período passou por importantes cidades do Triângulo Mineiro, entrando em Goiás e chegando até Catalão; atravessou o sudoeste goiano até Cuiabá, em Mato Grosso. Nessa maratona, construiu bons relacionamentos e realizou diversos serviços profissionais, como fotógrafo itinerante. Atuava principalmente como retratista, mas também realizava 
trabalhos mais especializados, como os álbuns com dados estatísticos e fotografias para as cidades de Catalão e Rio Verde, além da primeira edição de cartões postais em Uberlândia. Berto era muito comunicativo, bem-informado e ousado. Suas várias habilidades pareciam se adequar perfeitamente ao perfil de um pioneiro. Em sua passagem por Rio Verde ainda como fotógrafo itinerante, Berto conheceu o major Oscar Campos, então deputado estadual, e Jerônimo Coimbra Bueno, “construtor” de Goiânia, que o convidaram a trabalhar no Departamento de Divulgação e Propaganda da capital, após admirarem o álbum de fotografias que acabara de elaborar para a prefeitura de Rio Verde. Sua atividade como funcionário público durou pouco. “Minha índole não é ser empregado”, Berto dizia, numa entrevista de 1983, explicando sua inaptidão para aquele tipo de trabalho rotineiro. Dona Marta, sua esposa, comenta, em entrevista concedida em 2001, essa passagem da vida de Berto e elogia sua capacidade de relacionamento social:

Meu marido era uma pessoa de muito conhecimento. Era uma pessoa que lia muito. Ele tinha uma autodidática formidável. Qualquer assunto que a gente abordasse com ele, ele não fugia do assunto, sabe? Então, ele era uma pessoa que freqüentava, assim, pessoas de nível cultural elevado, eram amigos dele, porque ele também tinha sua cultura, ele também estudava, ele lia. Então, ele tinha boas amizades. E foi daí que surgiu essa amizade com o Oscar Campos, que o convidou pra vir a Goiânia. Aí como ele já tinha deixado a profissão de fotógrafo pra trabalhar aqui no Estado, ele encostou um pouco e aí apareceu essa gerência do cinema. Foi na época que eu o conheci, em 1938.

A direção do Cine Campinas foi a porta de entrada para o mundo cultural e a esfera da sociabilidade na junção Campinas-Goiânia. Berto, além de fotógrafo e desenhista, tinha um dote musical respeitável, o que o tornava freqüentador assíduo dos saraus e reuniões sociais. A professora Belkiss Spenzieri, pianista goiana de renome internacional, era muito jovem no início dos anos 40, mas ainda se recorda hoje das atuações de Berto como cantor, conforme declaração feita em entrevista em 2001:

Porque no princípio, de Goiânia, eu era a pianista, apesar de muito jovem; eu era muito novinha. Quando eu fui para o Rio de Janeiro, 
tinha 14 anos. [...] Eu tocava na Igreja Católica, tocava nas igrejas protestantes quando precisava, acompanhava cantores, fazia fundos, [...] eu acompanhava os instrumentistas todos. Depois de 42, quando a Rádio Clube de Goiânia, o Venerando [Venerando de Freitas Borges, o primeiro prefeito de Goiânia] então me chamou para ajudar. Então, eu tocava no programa de calouro, tocava no programa infantil. Então, eu era o quebra-galho para todas as ocasiões aqui. Eu corri de um lado para outro, e dois cantores muito, muito comuns no meu dia-a-dia, era o Sílvio Berto e o João Bercó. Eram os dois cantores que eram os mais atuantes e que tinham um repertório muito grande, e que cantavam em muitas festas. Então, os ensaios eram feitos lá em casa, para que a hora que eles chamassem, estivesse todo mundo pronto, preparado. Então, desde muito jovem, eu acompanhei Sílvio Berto. Sempre com um prazer muito grande. Ele era uma pessoa muito querida. [...] Dos movimentos, dos eventos musicais, eu me lembro dele sempre, todos. Quando havia música, Sílvio Berto era convidado para cantar, para participar. Então, ele cantava canções italianas com muito gosto. E ao passo que João [...] cantava trechos de ópera, então eram dois cantores com estilos diferentes.

Berto estreitaria mais ainda os laços com o meio artístico em Goiânia com sua atuação como speaker na primeira estação de rádio em Goiânia; chegou a ter um programa semanal, no qual cantavam músicas em italiano. O fotógrafo artista participou também de um movimento cultural, liderado pelo pianista alemão Érik Pipper, pelo arquiteto José A. Neddemayer e pela professora Amália Hermano, que originou a Sociedade Pró-Arte, congregando artistas e intelectuais que organizavam exposições de artes, reuniões de literatura e promoções musicais. A Sociedade Pró-Arte chegou a criar uma pequena orquestra, da qual fazia parte outro fotógrafo pioneiro de Goiânia, o armênio Haroutium Berberian, que tocava violoncelo. ${ }^{7}$ A Pró-Arte promoveu, em outubro de 1945, um concerto inaugural da entidade; Sílvio Berto participou não só do concerto, cantando a cançoneta italiana Ideale, de Paolo Tosti, mas também organizando uma exposição fotográfica com obras suas para o evento, talvez a primeira do gênero em todo o Estado de Goiás. Essas realizações testemunham como sua atividade fotográfica 
estava estreitamente relacionada com as formas de sociabilidade na capital emergente.

O Foto Berto era o estúdio mais requisitado em Goiânia. Todo acontecimento social, para ser reconhecido, precisava receber a chancela do Berto. Havia uma interdependência entre os focos de sociabilidade, a elite goianiense e o estúdio. Por um lado, o próprio fotógrafo identificavase em anúncios para jornais e revistas, como "o fotógrafo da elite de Goiânia”. Os retratos individuais e de família eram expostos em vitrinas no estúdio.
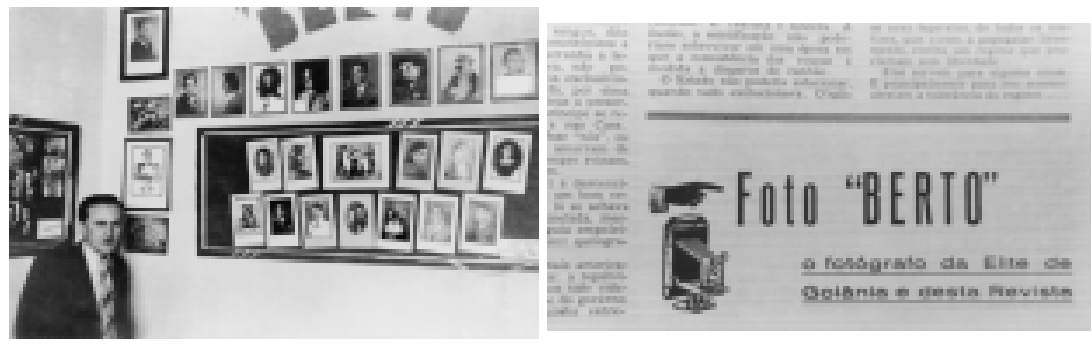

A sociedade, por sua vez, reconhecia-se e afirmava-se, retratada por Berto, que também documentava casamentos, formaturas, batizados, primeiras comunhões e eventos similares. Contudo, as imagens produzidas por Berto, ou pelos estúdios fotográficos na época, não poderiam ser consideradas representações "reais” dessas pessoas ou eventos. Tratava-se de imagens construídas; o estúdio fotográfico era uma "fábrica"» de imagens. O fotógrafo orientava, no estúdio, uma espécie de encenação, compondo “cenas” com auxílio de recursos de iluminação, além de cenários pintados ou construídos. O fotógrafo e as pessoas retratadas “construíam”, tacitamente, a imagem que surgiria, escolhendo as roupas, compondo os objetos, acertando as poses. Certamente a “direção” do fotógrafo sempre predominava sobre o repertório de escolha dos retratados, pois os fatores técnicos e as condições materiais do estúdio eram prerrogativas do primeiro. Ainda assim, esse privilégio técnico do fotógrafo é sempre regulado, na produção de retratos de estúdio, por fatores culturais que delimitam a aceitação da foto. Um perfil de corpo total, por exemplo, não é convencional num retrato de estúdio, embora 
seja obrigatório em fotos para identificação policial. Existe uma certa uniformidade na composição dos objetos no quadro, no arranjo das pessoas em fotos de famílias ou grupos, na iluminação, na técnica do retoque, que nos fazem "reconhecer" imediatamente um retrato de estúdio e diferenciálo, por exemplo, de fotos ou retratos produzidos, de forma amadorística, depois da popularização das câmeras portáteis. Berto era famoso por sua habilidade em retocar as fotos, aproximando a imagem final do "gosto" do cliente. A rememoração que Eleyson Rocha, seu assistente, faz do processo de fotografar no Estúdio Berto ilustra como a produção de retratos requeria uma habilidade técnica, mas envolvia também um acordo tácito subjacente, um tipo de “negociação” (GRANGEIRo, 1993, 1998) entre o profissional e o cliente. Em entrevista, Eleyson Rocha conta que Berto

retocava muito bem, com lápis, mesmo. Usava, assim, um tipo da acetona, você pega a chapa e passa aquele tipo de acetona e depois vai com o lápis, faz um contraluz a vai tirando os defeitos da chapa. [...] Ele às vezes fazia uma maquiagem na fotografia... É, inclusive ele, uma certa feita, pegou um senhor a candidato, ele era muito estrábico e ele fez o olho dele ficar normal... [risos], através do retoque, né? Ele fazia esses milagres aí...

Ainda que a habilidade técnica de Sílvio Berto pudesse distingui-lo de outros profissionais em Goiânia, na década de 1940, havia outros fotógrafos como Benito Bianchi que, nessa época, também eram reconhecidos pela maestria na técnica da foto em estúdio, em geral, e no aspecto do retoque, em particular. O reconhecimento e a produção do Foto Berto em Goiânia dos anos 40 e 50 endossariam, numa primeira leitura, a teoria da fotografia como imagem-ato. O significado dessas fotos decorreria do uso desse tipo de imagens no contexto social, que tem motivações individuais, como o desejo de se mostrar e de se perpetuar com boa aparência, mas também motivos de ordem social, como ilustrar coesão familiar, pertinência a grupos ou instituições, simbolismos de "ritos de passagem”, além de outros. O “ato fotográfico”, nesse caso, envolve um componente de intersubjetividade que não se apresenta ou é secundário em outros situações, como em "instantâneos” colhidos por amadores ou em fotos jornalísticas. A interação entre fotógrafo e cliente é fundamental para a qualidade do produto e isso explica o sucesso do Foto Berto em 
Goiânia. A condição de habitué nos círculos de sociabilidade proporcionava a Berto uma oportunidade para intuir o tipo de imagem ou cena que melhor conviria aos anseios subjetivos do cliente. Por outro lado, este se encontrava, em razão de sua familiaridade anterior com o fotógrafo, em condições melhores para demonstrar naturalidade ou espontaneidade no ambiente do estúdio, que, via de regra, é artificial. Entretanto, essa leitura pragmática, que valoriza fatores culturais e sociais como indícios da foto de estúdio, não pode desqualificar a dimensão técnica do ato de fotografar, que inclui, por exemplo, o processo químico de revelação e fixação da imagem. Privilegiar o componente subjetivo do reconhecimento da imagem e da possibilidade de sua perpetuação para o cliente acarreta, como contraponto, a necessidade de examinar também como o fotógrafo se reconhece em seu ofício.

Berto certamente desaprovaria ser considerado um retratista. Identificando-se como fotógrafo, reconhecia uma diferença entre a pintura e a fotografia, como afirma sua esposa Marta Berto: "Retrato, pode ser pintado a mão, e a fotografia não, é foto, luz gravada [usando gestos para explicar]. Então ele dizia que era fotógrafo, não um retratista...”. Essa idéia geral da fotografia se alinha a um realismo de matriz positivista que alimentou a concepção dominante sobre o tema na Europa, a partir de meados do século XIX. Como "luz gravada", a fotografia reproduz a natureza, por intermédio do processo ótico de captação da imagem e químico de revelação e fixação. A dimensão subjetiva do ato fotográfico é minimizada nessa concepção; a imagem é considerada independentemente de seu realizador. Gisèle Freund (1974, p. 74) analisando a atitude da época perante a respeito da fotografia, comenta que "o fotógrafo está ligado a uma realidade bem definida que ele pode corrigir, mas não transformar”. O fotógrafo, diferentemente do pintor ou retratista, é guiado por um processo racional cuja materialização é o aparato fotográfico; a produção fotográfica depende essencialmente do domínio da técnica, e não da intuição, da imaginação ou da criatividade. Contudo, admitir que Berto compartilhasse dessa atitude realista não implica inferir que ele opusesse a atividade artística ao ato de fotografar. A rivalidade entre pintura artística e fotografia, que alimentou tantas discussões teóricas na Europa do século passado, parece não ter repercutido no Brasil, mesmo nos centros pioneiros, como Rio de Janeiro, Ouro Preto, Recife e São 
Paulo (Ferrez, 1985; LiMA, 1998 [1991]). Longe de sustentar tal distinção, Berto, a despeito de sua maestria na técnica fotográfica em todas as fases do processo, compartilhava, em seu ofício, algumas características que o aproximariam dos pintores retratistas. A primeira delas é a preocupação com a identificação; Berto utilizava, tanto em retratos quanto em fotos “de reportagem”, ${ }^{9}$ marcas de identificação que variavam, tanto no formato quanto na técnica de gravação ou impressão. Quando utilizava negativos de vidro, Berto costumava gravar com pena e nanquim na superfície da emulsão o nome "Berto" ou "Foto Berto", ou ainda um logotipo estilizado:
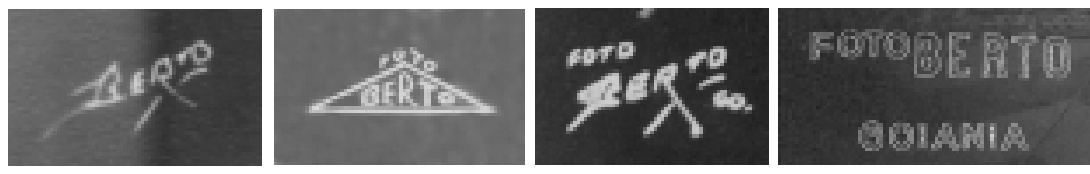

A marca se transferia, portanto, para todas as cópias dela originadas. Com a mudança para filmes flexíveis, a marca identificadora era estampada em alto relevo, sendo visível na própria imagem da foto (como na última das marcas expostas acima). Berto recuperava, com o uso dessas marcas, a prática dos pintores ou dos gravuristas de "assinar” suas obras, imprimindo nelas a marca de sua autoria e individualidade. $\mathrm{O}$ fotógrafo chegava inclusive a assinar as próprias cópias das fotos usando nanquim, “personalizando-as”, no dizer de seu assistente Eleyson Rocha. Ainda que a prática utilizada pelos fotógrafos de estúdio para identificação tenha se dirigido para a despersonalização da imagem, com o simples uso de um carimbo no verso da cópia ou mesmo com a abolição de qualquer sinal, Sílvio Berto conservava seu emblema pessoal, marca distintiva de seu trabalho, que se distinguia pela imersão nas formas de sociabilidade. Contudo, Berto não incluía sua marca em todas as suas fotos; provavelmente privilegiava as melhores, ou os retratos de pessoas de maior prestígio social. Segundo Eleyson, isso dependia “do tipo de fotografia. Numas ele fazia questão de pôr a assinatura. Outras carimbava, simplesmente”.

O Berto, do estúdio, era o mesmo Sílvio Berto dos saraus, das festas, do convívio com a elite goianiense, o locutor de rádio, membro do 
Rotary, que desenvolvia atividades filantrópicas e assistenciais... Suas marcas de identificação se multiplicavam nas fotos, nas propagandas exibidas no Cine Teatro Goiânia e no Cine Campinas, nos letreiros do estúdio, em anúncios de jornais. Esses sinais expressam, em algumas de suas formas, a complementaridade entre arte e técnica no trabalho do fotógrafo. Tomemos como exemplo a logomarca abaixo, impressa nas capas de retratos de estúdio confeccionadas por Berto nos anos 40 .

A logomarca é uma composição criativa de signos contrastantes da tradição e da modernidade. No canto superior esquerdo, a objetiva de uma câmera fotográfica estilizada é emoldurada por um ramo de café, numa clara analogia visual com um brasão oficial. O elemento da aristocracia, simbolizado pelo laurel, contrasta com a referência à modernidade técnica, simbolizada pela objetiva fotográfica. A inscrição "Foto Studio”, que preenche uma das diagonais da figura, simula a escrita caligráfica, usando caracteres rebus-

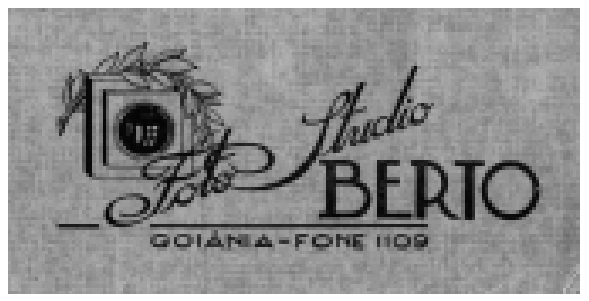
cados, o que também remete à tradição. No canto inferior esquerdo, o dístico Berto estabelece outro contraste, pois está escrito com caracteres art déco, remetendo ao

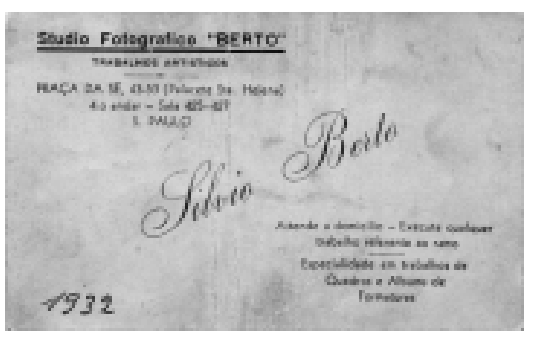
cubismo e à arquitetura moderna e designando, ao mesmo tempo, a pessoa do fotógrafo e seu estúdio, que recebe da inscrição em diagonal a conotação tradicionalista. Berto compôs diversas variações em torno desses elementos gráficos contrastantes, harmonizando com o tipo de uso que lhes era destinado. Em anúncios e letreiros, a marca de identificação sempre aparecia em estilo déco, numa tendência modernizante, em oposição ao qualificativo "fotógrafo da elite”, geralmente associado. No entanto, em seu cartão de visita, utilizado em ocasiões de interação pessoal, o nome "Silvio Berto" despontava em destaque, com escrita caligráfica pomposa, em contraste 
com a identificação do estúdio em caracteres retos, no canto superior esquerdo.

O uso de retoques é outra característica que aproxima Berto da pintura artística. Fugindo do realismo naturalista, nesse ponto, o fotógrafo construía, por meio de sutis detalhes, acrescentando sombras e linhas, uma imagem mais a gosto do cliente. Afinal, a fotografia de estúdio proporcionava ao cidadão comum a oportunidade de, a um custo acessível, possuir um retrato, reproduzir sua imagem em cenário e pose adequados ao gosto da época e à sua própria vontade, privilégio antes reservado a pessoas de alto poder aquisitivo. Contudo, a “democratização” do acesso ao retrato fotográfico, conquista do desenvolvimento técnico, não eliminou, mas recriou com novas nuanças o acordo tácito que era estabelecido entre o pintor de retratos e a personalidade a ser retratada. As imagens produzidas por fotógrafos que, como Berto, se dedicavam preponderantemente ao gênero de “reportagem social”, tanto em estúdios fixos como na forma itinerante, compartilhavam o caráter de "imagens negociadas” com as realizações dos pintores retratistas da elite social (Grangeiro, 1993, p. 39-41; Miceli, 1996).

Qual é o significado da fotografia de “reportagem social” feita por Berto? Recorrendo à concepção pragmática que nos orienta, diríamos que o significado está preponderantemente relacionado com a prática do fotógrafo profissional de estúdio, cujo sucesso depende não só do domínio técnico, mas da interação com o cliente, conduzindo a um resultado que agrade a ambos, o fotógrafo e seus cânones estéticos e técnicos, herdados das “oficinas fotográficas” do século passado e, por outro lado, o gosto e os anseios sociais do cliente. Assim compreendemos como a imersão de Berto nos círculos de sociabilidade da Goiânia emergente foi fundamental para seu reconhecimento e consagração. Porém não devemos menosprezar a dimensão icônica da fotografia de "reportagem social", ou seja, o fato de que as pessoas conservam e exibem fotografias em álbuns e porta-retratos para cultivar imagens que, além de serem indícios de pessoas que existem ou de eventos que aconteceram, são aprazíveis, são bonitas. As pessoas e eventos são retratados em cenários e poses que os destacam e singularizam, apesar do seu caráter encenado e artificial. Em outras palavras, as imagens indicam certos eventos, pessoas ou situações reais, representadas em analogia com a percepção ótica; a 
circulação e o consumo de tais imagens são a prova da validade e do reconhecimento social dessa analogia. Portanto, as fotografias do Estúdio Berto, consideradas na maioria das situações da época histórica de sua produção, circulação e recepção, constituem signos indiciais icônicos, fazendo uso da terminologia de Peirce e dos que a interpretaram (Dubois, 1998; SchaefFer, 1996, SANTAELla e Noth, 1999; Sonnesson, 1999, entre outros). Contudo, ainda veremos que o elemento simbólico da fotografia de estúdio de Berto, tida como signo fotográfico, incipiente nessa época, toma vulto no decorrer do tempo; por ora, julgamos que as perspectivas do índice e do ícone aparecem em maior grau no exame das fotos de “reportagem social”, consideradas em sua época.

\section{As vistas urbanas}

A produção de vistas fotográficas avulsas e álbuns por Sílvio Berto deve ser considerada em seu nível contextual específico. Seria imprudente compararmos as condições desse tipo de produção com outras situações já examinadas na história da fotografia no mundo ou no Brasil, como a febre do consumo de cartões postais turísticos baseados em vistas fotográficas (Freund, 1974, p. 96-97), ou mesmo a produção do álbum comparativo da cidade de São Paulo editado por Militão Augusto de Azevedo em 1887. Certamente Berto, que possuíra um estúdio na Praça da Sé, em São Paulo, inspirou-se na popularização dos cartões postais e na importância da fotodocumentação na divulgação da imagem dos centros urbanos para se lançar na produção de vistas urbanas e na confecção de álbuns comemorativos. Entretanto, embora houvesse certa semelhança com relação ao público consumidor de tais produtos, havia diferenças consideráveis em relação às condições de produção. Não havia, tanto nas cidades do interior em que Berto elaborou álbuns comemorativos quanto na fase inicial do desenvolvimento de Goiânia, condições para o barateamento de vistas ou álbuns pela produção em caráter industrial, nem do envolvimento dos setores gráfico, editorial e de vendas. Tratava-se de uma produção artesanal. Os álbuns eram individuais, com as fotografias feitas e retocadas por Berto, que também fazia as inscrições, desenhos e molduras. Certamente havia, como no 
caso do famoso álbum de Militão, um interesse político e um caráter “oficial” na elaboração desses álbuns como registros documentais, mas é evidente a discrepância, em termos políticos, econômicos ou simplesmente demográficos, entre a nova capital no interior do Brasil e os grandes centros industrializados.

As vistas urbanas eram produzidas a partir de cópias dos negativos de vidro, utilizando um papel especial, que vinha de São Paulo, já com as inscrições no verso, na forma de um cartão postal. Berto e seu assistente utilizavam a mesma câmera de madeira, com sistema de fole, empregada no estúdio, para fotografar vistas externas da cidade. Posteriormente, passaram a usar uma Graflex Speed Graphic, famosa câmera norte-americana especialmente adequada para fotorreportagens, que já trabalhava com film packs, possibilitando fotografar sucessivamente. O depoimento de Eleyson Rocha a respeito das tomadas de vistas urbanas é bastante esclarecedor sobre o caráter do processo; sem dúvida, tratava-se fundamentalmente de um enquadramento cênico, e não de um instantâneo:

Nós fazíamos vistas da cidade. Nós colocávamos a máquina, na Avenida Goiás, no lugar certo, focalizava, tudo direitinho. Então nós convidávamos os donos de carro da cidade para passarem naquele momento oportuno pra gente fotografar, porque não havia tanto movimento de carro [risos]. Eles eram chamados, vinham, paravam ali, naquela hora, né, e a gente batia. Podia bater à vontade, até de mais perto, ela não tremia, porque os carros ficavam ali... No início era assim...

As vistas urbanas eram expostas e vendidas individualmente em seu estúdio, que, a partir de 1947, também passou a incluir uma loja de material fotográfico. Algumas passavam por um processo de montagem, gerando cópias com molduras ovais e inscrições. Berto produzia ainda pequenos álbuns encadernados com cartolina, contendo reproduções das vistas em tamanho menor, para venda em sua loja. A maior parte das vistas de Goiânia feitas por Berto é do início dos anos 50; algumas chegaram a ter edição gráfica, barateando seu custo e gerando postais no sentido mais exato do termo. Berto escolheu várias vistas produzidas 
neste período e mandou colori-las à mão, encaminhando-as a São Paulo; foram os primeiros cartões postais em cores da nova capital.
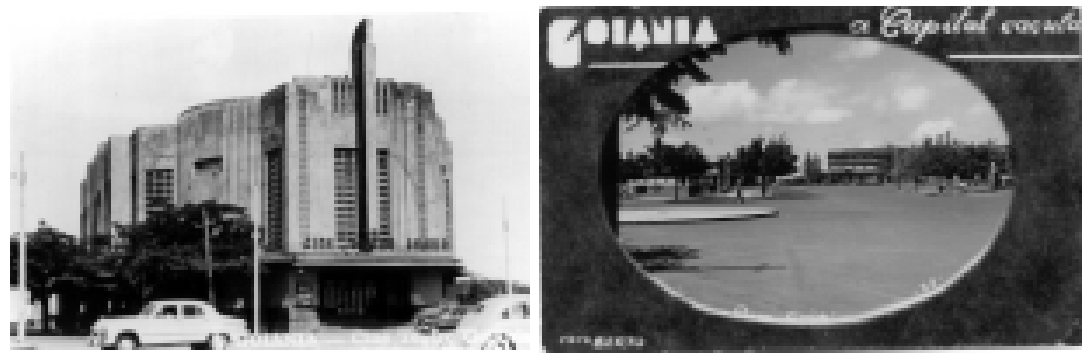

Ainda que as vistas, álbuns e postais de Berto não se tenham beneficiado propriamente da reprodutibilidade técnica trazida pela indústria e pelos meios de comunicação de massa, cabe a esse gênero de fotos uma importante função social: constituir e transmitir o imaginário urbano que, no caso de Goiânia, estava vinculado ao discurso modernizante e ao espírito desenvolvimentista sob a égide do Estado Novo. No que se refere à história da fotografia, acatamos aqui as considerações feitas por Solange F. de Lima a respeito da mudança estética trazida pelas vistas urbanas, o conjunto de vistas de Berto, mesmo considerado em seu limite contextual, também contribuiria

para o desenvolvimento de uma linguagem própria que, através da exploração de qualidades específicas, começa a impor parâmetros estéticos distintos da pintura. No discurso que a fotografia engendra a palavra-chave é comunicação. Comunicação de referentes que se pretendem comuns para o conjunto da sociedade. (LimA, 1998, p. 79)

Berto, o estrangeiro que não esteve de passagem, mas que chegou como um pioneiro e se estabeleceu em Goiânia, acatava os valores do discurso desenvolvimentista e suas vistas urbanas acabaram constituindo uma parte desse discurso que exaltava a modernidade e testemunhando a presença do planejamento estatal no desenvolvimento do interior do Brasil, o sucesso da Marcha para o Oeste, apregoada por Getúlio Vargas, que partia de Goiânia. A adesão tácita ao discurso desenvolvimentista 
não implicava uma submissão do fotógrafo aos interesses da elite goianiense, e sua autonomia pode ser explicada pela análise sociológica da objetividade do estrangeiro feita por Simmel (1983, p. 184):

O estrangeiro não está submetido a componentes nem a tendências peculiares do grupo e, em conseqüência disso, aproxima-se com a atitude específica de 'objetividade'. Mas a objetividade não envolve simplesmente passividade e afastamento; é uma estrutura particular composta de distância e proximidade, indiferença e envolvimento.

Apesar de participar dos grupos de sociabilidade que reuniam famílias tradicionais do estado de Goiás, sua condição de estrangeiro fazia com que sua posição nesses grupos fosse determinada, essencialmente, pelo fato de que ele não pertencia a eles desde o início, mas que transmitia qualidades que não poderiam emergir dos próprios grupos (SimmeL, 1983, p. 181). A sua simpatia pelos ideais desenvolvimentistas nos parece, assim, não uma assimilação ideológica ou por conveniência à propaganda oficial, mas uma identificação com o espírito pioneiro trazida pela sua condição social de estrangeiro, na acepção simmeliana. O próprio Berto, na entrevista de 1983, comparando a construção de Brasília com a construção de Goiânia, torna razoável nossa interpretação:

Quando se diz “vamos construir uma capital”, a pessoa pensa logo: o governo vai fazer a cidade. É verdade ou não é? O governo não faz a cidade, faz a estrutura da cidade, faz as ruas, faz os prédios oficiais; quem faz a cidade é o povo, é aquele que compra um lote, que constrói uma casa comercial, um boteco...

\section{A foto documental}

Berto nunca foi fotógrafo documentarista oficial, nem trabalhou regularmente como repórter fotográfico em algum jornal ou revista. Contudo, colaborou eventualmente para o governo, fotografando eventos comemorativos, solenidades, competições esportivas (aproveitando sua condição de apresentador e locutor). Chegou a acompanhar o então 
governador Pedro Ludovico a viagens pelo interior, como "fotógrafo oficial”. O fotógrafo captava, com muita sutileza, os atributos do poder e da autoridade, traduzindo-os em linguagem visual, por meio de enquadramentos sugestivos. Dominando os recursos cênicos e dramatúrgicos do estúdio, Berto acentuava ou destacava elementos do quadro, mediante ângulos e deslocamentos criativos nas tomadas, conferindo outro significado aos elementos da cena, enfatizando uns e suprimindo outros. Esse deslocamento do sentido solicita a interpretação do receptor, exige certo conhecimento do contexto, da situação retratada, para possibilitar uma leitura coerente. Em várias das fotos documentais de Sílvio Berto fica evidente a perspectiva do signo fotográfico como signo simbólico, além de indicial e icônico. O grau simbólico varia conforme o meio ou a situação da recepção, mas também de acordo com o tipo de envolvimento ou de conhecimento que o receptor tem a respeito da situação retratada. Temos nas duas fotos reproduzidas abaixo exemplos de identificação mais imediata da dimensão simbólica.

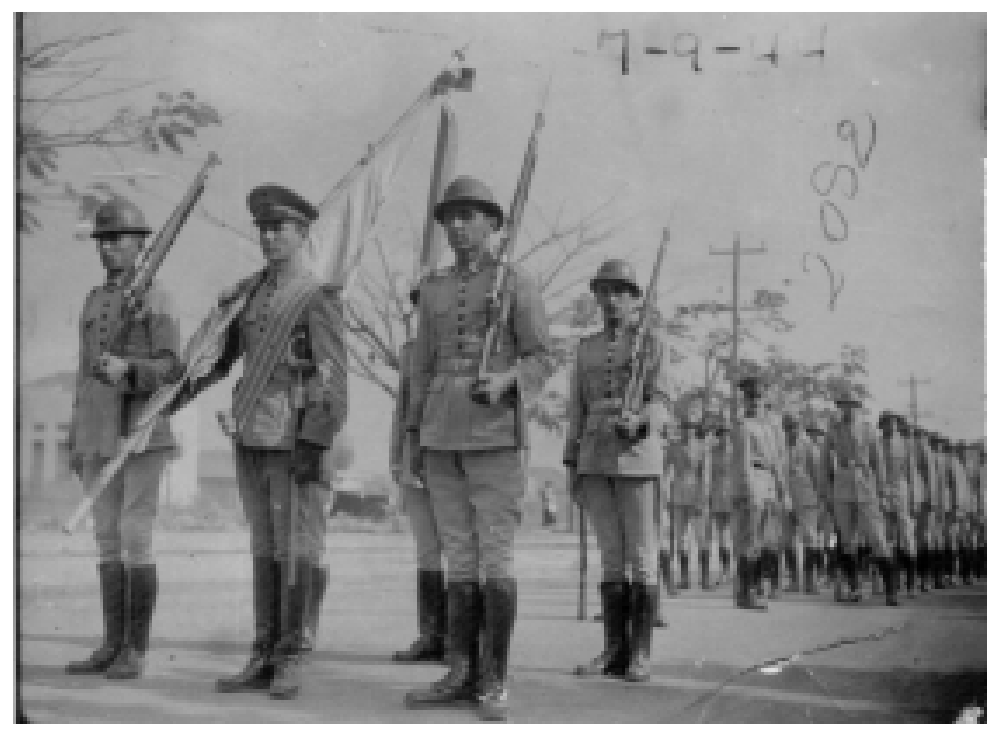




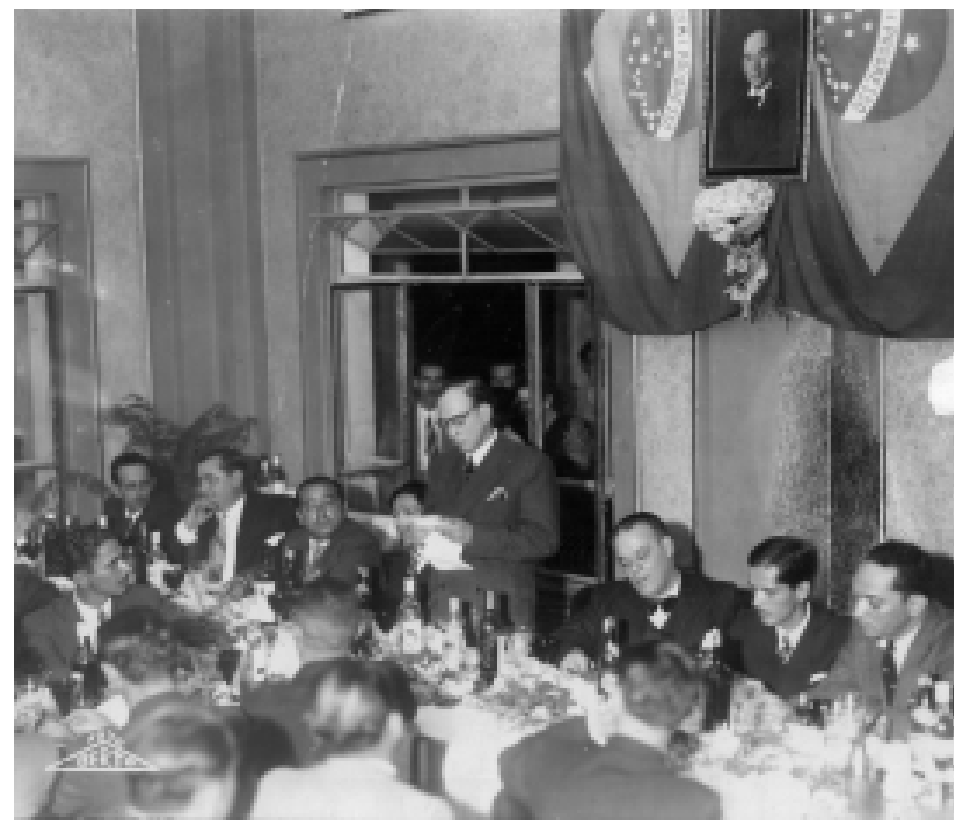

A foto à esquerda de uma parada militar nos impressiona primeiramente pelo enquadramento primoroso; parece um exercício de perspectiva artificialis feito por um pintor experiente. Podemos traçar linhas imaginárias em direção a um ponto de fuga no canto inferior direito, passando não somente pelas cabeças e pés dos militares, mas também pelos fios elétricos instalados nos postes da nova capital. O ordenamento geométrico, racional, da cidade e a formação dos soldados se harmonizam. Entretanto, uma formação militar envolve não apenas a ordem, mas também a hierarquia. O ângulo do enquadramento faz sobressair claramente o oficial que carrega a bandeira, símbolo nacional, escoltado por soldados armados com fuzis e baionetas. O pelotão alinhado aparece incompleto, sugerindo uma infinidade de homens na direção do ponto de fuga. Já não se consegue distinguir rostos no pelotão, enquanto no grupo armado e no oficial com a bandeira eles estão no foco, bem nítidos. A foto à direita mostra uma fala de Pedro Ludovico durante um jantar no Jóquei Clube. O governador e fundador de Goiânia está no centro da foto, mas Berto faz uma composição inusual, destacando, no quadrante 
superior direito, o arranjo feito com duas bandeiras nacionais e um feixe de flores emoldurando um quadro do próprio Pedro Ludovico, em traje oficial. A tomada em ângulo da mesa diminui o efeito da proeminência do chefe: um anfitrião, à mesa com seus convidados, num momento em que se levanta para tomar a palavra. No entanto, o destaque dado ao quadro identifica o personagem político. No canto direito superior, a legenda simbólica do homem de Estado; no canto inferior oposto, a marca de Berto, fotógrafo e freqüentador dos grupos de sociabilidade; ao centro, o governador, quase como homem comum, de óculos, ao lado de seus convidados à mesa. Berto humaniza Pedro Ludovico, mas também nos lembra de sua condição de chefe político e estadista, equilibrando, espacial e simbolicamente, o quadro da foto.

Berto fotografou praticamente toda a elite política de Goiânia em seu estúdio; tal trabalho se inclui na categoria de reportagem social, e não de fotodocumentação. Contudo, algumas dessas fotos foram aproveitadas em outras situações, das quais a mais significativa foi a colaboração feita à Revista Oeste, que utilizou ad hoc retratos e vistas produzidos para outros propósitos no estúdio ou em viagens para documentação de obras do estado de Goiás. Tais imagens adquiriram, com sua inclusão na revista, uma dimensão simbólica que não apresentavam nas situações originais de produção, distribuição e consumo.

A Revista Oeste, ${ }^{10}$ que circulou de julho de 1942 a dezembro de 1944 no estado de Goiás, desempenhou, principalmente na fase de março de 1943 a fevereiro de 1944, uma importante função de divulgação políticoideológica do Estado Novo. O governo estadual, nessa época, patrocinava as edições e indicava o corpo editorial. A revista, por sua vez, apoiava o Governo Federal e, segundo a análise de Eliane Dayrell (1977, p. 52),

endossava as bases teórico-ideológicas do Estado Novo, responsabilizando-se pela sistematização e divulgação do estadonovismo goiano, instalando um culto de personalidade ao Interventor, nos moldes em que se cumpria o culto nacional ao Presidente Vargas.

Há 66 fotos com a marca de Berto, sendo 21 diferentes e 45 repetidas, de um total de 270 fotos impressas nos 23 números publicados da Revista Oeste. A maioria das fotos de Berto identificadas é de retratos 


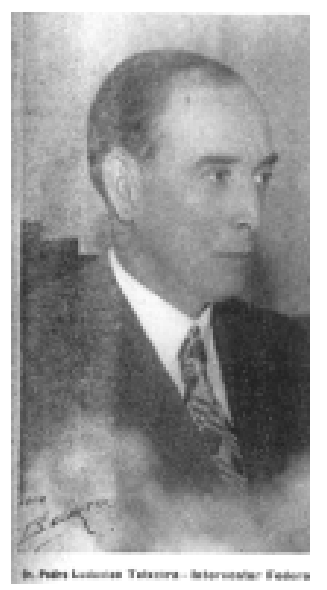

de personalidades da elite local (59), como Pedro Ludovico (reproduzido ao lado, aparece 13 vezes) e sua esposa Dona Gercina, Bernardo Élis (escritor, um dos redatores da revista), José Bernardo Félix de Souza (secretário da revista), Venerando de Freitas Borges e Colemar Natal e Silva, além de outros. Há apenas sete fotos que fogem dessa linha de retratos: são paisagens, vistas, fotos de logradouros ou de obras de Goiânia ou cidades do interior de Goiás. Essas fotos são, em geral, meramente ilustrativas, não se referindo ao contexto. Por outro lado, as fotos de personalidades geralmente acompanham artigos dos próprios retratados, ou o conteúdo versa sobre suas pessoas. O retrato de Pedro Ludovico feito por Berto aparece, invariavelmente, em todas as revistas a partir do número 6, confirmando a tendência ao culto pessoal do interventor.

Embora as fotos de Berto que aparecem na Revista Oeste não tenham sido feitas para o periódico, mas apenas aproveitadas, o fotógrafo não se esquivou de reafirmar sua filiação ao círculo de sociabilidade em Goiânia e de, por alguma forma, não ser estranho ao círculo de políticos e intelectuais que participavam da revista. $\mathrm{O}$ anúncio que aparece em vários números, com pequenas variações, reproduzido na página 9 , constitui uma prova de que a colaboração na Revista Oeste, ainda que parcial, constituiu um meio para consolidar o reconhecimento de Berto e de seu estúdio junto à elite goianiense. Entretanto, daí não podemos derivar que o fotógrafo estivesse ativamente engajado na formulação do discurso ou da propaganda estadonovista, ou que estivesse motivado para tal. Berto parecia reconhecer a diferença entre classes e o fato de que a proximidade com Pedro Ludovico e a participação na esfera da sociabilidade não lhe conferiam, per se, uma eqüidade no círculo do poder.

Quando se olhava para Pedro Ludovico o pensamento vinha para Goiânia. Mas não é como hoje, quando qualquer um pode fazer perguntas. Entre Pedro, o interventor, e eu, um simples retratista, havia uma distância. Fiz amizade com ele, mas não foi uma amizade íntima, uma amizade em que eu pudesse entrar em assuntos que não eram do meu alcance. (Entrevista concedida por BERTO em 1983) 
Independentemente da motivação pessoal ou do grau de envolvimento de Berto com o regime político, é inegável que a presença de suas fotos, em geral acompanhadas de logomarca, na Revista Oeste, acarretava um deslocamento de significado em relação a seu uso comum, na relação entre estúdio, fotógrafo e cliente. Afinal, a revista foi

um veículo a serviço da ideologia revolucionária, principalmente ao Estado Novo. Ela atuou na política de interiorização de Vargas, em momentos como a construção de Goiânia e a Marcha para o Oeste, e nesse contexto, cultuava as figuras de Getúlio e de Pedro Ludovico. (Costa, 1994, p. 123)

A tentativa de aproximar ideologicamente as duas lideranças foi marcante, especialmente no número 4 da revista. Abrindo o conteúdo da revista, nas páginas 2 e 3 , dois artigos, encabeçados pelas fotografias de Vargas e Pedro Ludovico, chamavam a atenção. A composição apresentava uma simetria visual impressionante, colocando em paralelo os textos (do mesmo tamanho e com o mesmo número de colunas) e fotografias, com os cabeçalhos "O operário número 1 do Brasil", para Vargas, e "O operário número 1 de Goiaz”, para Pedro Ludovico. Vargas aparece como o "Salvador da Pátria", um predestinado que prepararia o país para os novos tempos, que veio numa época de "transição entre um mundo que morreu e um mundo que nasce”. Os elogios às qualidades pessoais e às obras dos dois estadistas são inúmeros; Ludovico é comparado a Pedro, o Grande, da Rússia, em razão da vontade firme, da inteligência intuitiva e da honestidade insuperável, que são a raiz de seus triunfos e suas obras. No entanto, o texto enaltece uma qualidade sobre as demais, a humanidade de Pedro, o "homem do povo, que compreende o povo. Em conversas, em discursos; no lar, nas ruas, no palácio; em todas as suas palavras e atitudes" (Revista Oeste, edição comemorativa, p. 137). Berto expressou, convincentemente em linguagem visual, em várias de suas fotos documentais, as duas facetas que esse tipo de discurso sobre Pedro Ludovico construía: o estadista e o homem do povo.

A imagem reproduzida a seguir já foi publicada em vários livros sobre a história de Goiânia e em edições comemorativas de jornais; foi também exibida em exposições fotográficas. Representa, segundo nossa 
leitura, um dos melhores trabalhos de Berto, aquele no qual a dimensão simbólica do signo fotográfico se torna proeminente, embora possa também conduzir a leituras parciais, com destaque na dimensão icônica ou indicial. A interpretação dessa foto envolve a argumentação da análise precedente, constituindo um tipo de aplicação da concepção pragmática da fotografia que nos orientou.

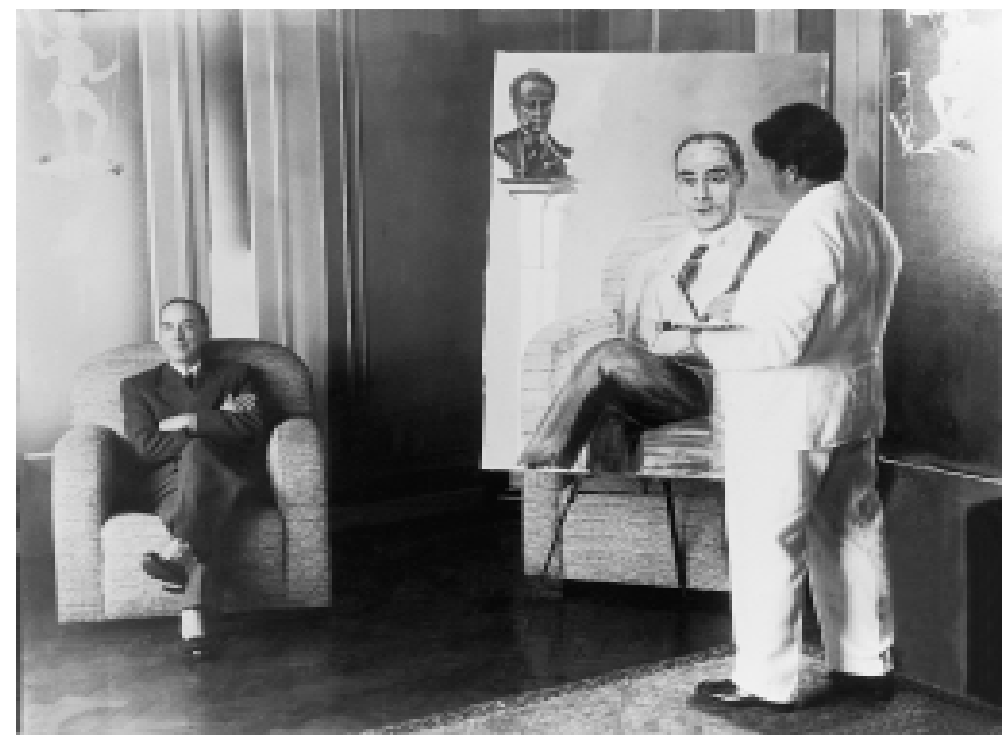

O ambiente da cena retratada é uma sala do Palácio das Esmeraldas, residência oficial do governador. Tratava-se de uma sala de estar íntima, onde Dona Gercina costumava tomar chá com suas amigas, situada no primeiro pavimento do Palácio (hoje é conhecida como Sala de Chá Dona Gercina). O arranjo simétrico entre as pessoas, móveis e objetos que compõem o quadro evidencia uma composição artificial, típica de fotos de estúdio. Na metade esquerda do quadro está Pedro Ludovico, sentado numa poltrona, quase alinhada em relação à superfície da porta da sala, em vidro jateado com gravação de um índio estilizado em bisotê. A porta dá para uma sala de refeições íntima. No lado direito temos o pintor Almeida Carvalho, ${ }^{11}$ que retrata o interventor, usando um cavalete em frente a outra poltrona, simetricamente alinhada em ângulo com a 
primeira. A superfície de fundo, do lado esquerdo, é outra porta em vidro jateado com gravura em motivo similar, dando para um corredor do palácio. O eixo de simetria é uma bissetriz imaginária que divide o aposento e cujo vértice aproximado é o canto formado pelas duas paredes, situado na região escura entre as duas poltronas, invisível na foto. A imagem do lado direito do quadro é como um reflexo da imagem do lado esquerdo, se considerarmos apenas o interventor sentado em sua poltrona. $\mathrm{O}$ fato de que houve um montagem da pose fica evidente ao notarmos que a tela, praticamente já terminada, retrata o interventor sob outro ângulo. Temos, à esquerda, o Pedro Ludovico humano, homem do povo, sorridente, tranqüilo, na sala de estar de sua casa. Em seu "reflexo" à direita, o Pedro estadista, mais sério, menos à vontade, ao lado de um busto de Getúlio Vargas. A composição magistral feita por Berto na foto requer alguns comentários:

- Pedro demonstra naturalidade ao posar para Berto, em razão das relações amigáveis mantidas com o fotógrafo, que era freqüentador de festas e reuniões no palácio. O olhar despreocupado denota a espontaneidade na postura. Mauro Borges, filho de Pedro Ludovico e ex-governador de Goiás, reviu essa imagem, em novembro de 2000 e, indagado sobre a naturalidade da pose na ocasião, comentou: "Esse é o meu pai, está à vontade e sorrindo. Ele era assim mesmo!”. Por outro lado, comentando a tela de Almeida Carvalho em relação a seu pai, observou: “Aqui é o governador, todo sério, fazendo pose...”. Berto usa um artifício para convergir, no mesmo quadro, o Pedro estadista e o Pedro humano, homem comum.

- A fotografia indica o real, mostra que “alguma coisa está lá”, é um tipo de testemunho da percepção. Essa é a “tese da existência”, que justifica a validade da foto documental e que valida a idéia de que a foto é prova de alguma coisa. Segundo Schaeffer (1996, p. 112), a tese da existência funciona como "uma verdadeira implicação lógica que liga a imagem à existência daquilo de que ela é a imagem”. Já no caso da pintura, ou da imagem pictórica, podemos dizer que ela representa alguma coisa e que essa coisa pode não existir. Assim, Berto parece nos dizer: "eis aqui, à esquerda, o Pedro Ludovico real, que conheço, do qual sou amigo. Olha lá, à direita, naquele quadro, o 
Pedro Ludovico que é convencionalizado como homem de Estado, que age como estadista, mas que, na realidade, é o ser humano que conhecemos em seu círculo social mais íntimo".

- Esse jogo entre o que existe, e o que é construído, mas que também se torna real, aparece num importante

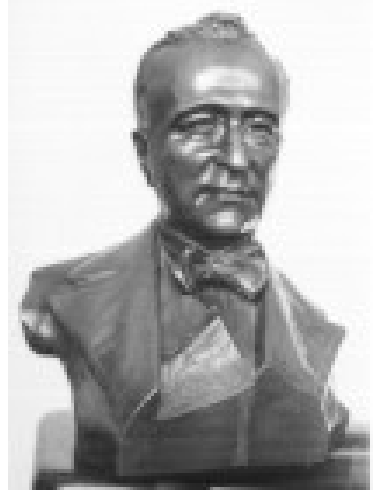
detalhe visual. Trata-se do busto de Getúlio Vargas, ${ }^{12}$ reproduzido na foto ao lado, que não aparecia na cena, mas que provavelmente estava mais à esquerda e fora habilmente oculto na composição de Berto. O objeto que simboliza a aliança com o governo federal e a pessoa de Vargas, ao mesmo tempo conotando a importância político-ideológica do culto à personalidade do homem público no Estado Novo, permanece apenas na construção do pintor que apenas pode representá-lo, mas não pode mostrar ou provar sua existência.

- Berto, a despeito de se identificar com a fotografia como "traço" objetivo do real, como "luz gravada", admirava também a pintura artística. José Luiz Bittencourt, membro da Academia Goiana de Letras, comenta, num artigo recentemente publicado num jornal goiano, essa afinidade estética, numa descrição do Foto Estúdio:

No ateliê de Silvio Berto a gente tinha a impressão de que estava em Veneza ou na ilha grega de Creta, pois ali eram abundantes as gravuras de Bellini, Tintoretto, Veronese e Ticiano, compatriotas do século XVI, que lhe despertavam a mesma admiração estendida a Michelangelo, Giulio Clovio e aqueles outros da linhagem artística que a Itália ofereceu ao mundo. (Diário da Manhã, 13/8/2001)

Berto se aproxima da arte pictórica e do signo icônico ao trabalhar com analogias, articulando elementos visuais no interior e fora do quadro e solicitando, para uma boa interpretação, o conhecimento prévio de uma realidade social que também é extra-quadro. É oportuno, nesse aspecto, recordar a habilidade com que Velázquez utilizou esse 
tipo de recursos no quadro Las meninas, reproduzido adiante (c. 16561657). A menina em destaque no centro é a infanta Margarita, herdeira do trono espanhol, rodeada por suas damas de honra; o pintor é o próprio Velázquez, que está retratando o casal real, Filipe IV e sua segunda esposa, Maria Ana da Áustria, que só são visíveis no espelho ao fundo. Velázquez dá destaque à provável herdeira e retira a realeza do quadro, ainda que deixando indícios de sua presença, como a imagem no espelho e o olhar atento do pintor. Outros elementos que dão sentido à pintura pertencem à conjuntura de sua época e hoje são domínio da História, como o absolutismo monárquico na Espanha do século XVII e o Renascimento cultural. O conjunto de indícios é que nos permite interpretar o famoso quadro de Velázquez como uma crítica não só ao regime político mas também ao realismo pictórico, ou à idéia da arte como imitação da natureza ou da realidade.

Berto, de forma similar, trabalhou no retrato de Pedro Ludovico com a percepção espacial, utilizando um criativo arranho de pessoas e objetos. Não podemos dizer que a pintura e a fotografia sejam tão diferentes em relação à captação e representação da realidade visual, pois a própria câmera fotográfica é uma aparelho que visa produzir a perspectiva artificialis, sistema de representação em duas dimensões desenvolvido através do dispositivo da câmera obscura na Renascença - portanto, um sistema de representação historicamente determinado (Machado, 1984, p. 63-76). A novidade, no caso de Berto, está em articular não somente dois sistemas de representação diferentes, a fotografia e a pintura, mas dois tipos de resultado de uma ação: a de fotografar e a de pintar, numa mesma imagem. Ao observarmos

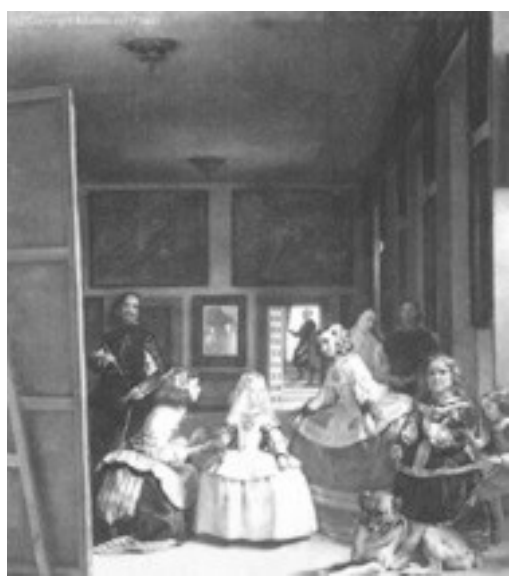
essa foto de Berto, no momento da recepção do ato fotográfico, somos levados a questionar a idéia da fotografia como um tipo de reflexo que ao mesmo tempo atesta a existência 
do real. O choque na recepção decorre da simetria, do efeito especular entre os lados esquerdo e direito da imagem. A imagem de Pedro Ludovico à esquerda que, socialmente condicionados pela "tese da existência”, consideramos como indicativa do Pedro "real”, uma pessoa comum, despreocupada, é refletida na tela do pintor, que nos remete ao Pedro estadista, associado com o busto de Vargas, que não vemos do lado esquerdo. A diferença nítida entre as duas imagens de Pedro reforça o choque e nos conduz a acatar a imagem humana de Pedro como um humano e tolerar a do estadista, que percebemos como construída subjetivamente pelo pintor. Berto nos transmite sua versão do discurso estadonovista que articula a persona do governante com a ação do Estado e esta com o desenvolvimento social. Nesta, o fotógrafo tende a valorizar simbolicamente a figura que faz parte dos círculos de sociabilidade, pois as formas de sociabilidade constituem o sustentáculo de sua própria identidade profissional construída como “fotógrafo da elite”. Essa figura não coincide com o perfil de Pedro como político, que racionalmente persegue seus objetivos levando em conta as leis do Estado, numa leitura plausível da imagem de Pedro na tela de Ameida Carvalho. Porém, a própria concepção da fotografia como "prova” do real, socialmente disseminada e, pelo menos na época de Berto, aceita sem reservas, ${ }^{13}$ nos impede, numa recepção imediata, de perceber o processo de construção, por parte do fotógrafo, que ela envolve. Somente a atividade da interpretação, que se requer para a efetividade do signo simbólico, pode revelar esse processo construtivo, que, para ser explicada, requer que consideremos o ato fotográfico numa acepção mais ampla, levando em conta não só os momentos de sua produção, mas também os da circulação e da recepção.

\section{Agradecimento}

Agradeço aqui a colaboração direta de minha esposa, Stela Horta Figueiredo, técnica da equipe do Acervo Fotográfico, que providenciou o material disponível no MIS para reproduções e fotografou diversos documentos e objetos necessários para a reconstrução histórica. Este estudo não seria possível sem a sua participação. 


\begin{abstract}
The article analyzes, based on a pragmatic conception of the photographic act, the professional activity of Sílvio Berto, a pioneering photographer in the city of Goiânia. The meaning of his works, in any kind of photography developed ("social documentation", urban views and photo documentation), is related to social interaction in situations of production and reception of photo studio images. Berto, habitué of sociability circles in the emerging capital, constructed a professional identity that assimilated, by one side, elements of the modernity discourse that constituted the imaginary of Goiânia. Nevertheless, he recovered, by another side, attitudes and values from portrait painters, besides some features of "social documentation" photography performed in Brazil since the early 20th century.
\end{abstract}

Key words: Photographic act, social report, sociability.

\title{
Notas
}

1. Para uma boa introdução ao tema, consultar Sonnesson (1999) e Santaella e Nöth (1999 [1997]).

2. Poderíamos incluir aqui a teoria da estruturação social de Anthony Giddens (1989 [1984]) e diversas tendências no interacionismo simbólico Blumer (1969) e Goffman (1984).

3. O suporte documental deste trabalho provém do Acervo Fotográfico do MIS de Goiânia, que nos disponibilizou, para consulta, o seu banco de dados informatizado, bem como a reprodução de fotos digitalizadas, algumas aqui reproduzidas. Tivemos acesso também às entrevistas com familiares de fotógrafos pioneiros colhidas para o Projeto Pioneiros da Fotografia em Goiânia e a um dossiê de informações coletadas em jornais e revistas da época da construção e consolidação de Goiânia, material indispensável em nossa análise, que está discriminado no final deste trabalho.

4. As informações sobre a vida profissional de Berto originam-se de "O fotógrafo Sílvio Berto”, segundo número da série Cadernos de Fotografia lançada pelo MIS-Goiânia. Foram consultadas também as anotações feitas por Stela Horta para a elaboração do Caderno.

5. Em meio à temática da construção de Goiânia, que conta com uma literatura considerável, pelo menos em nível regional, destacamos Bernardes (1998) e Oliveira (1999) no que se refere à questão da modernidade no planejamento e na cultura da cidade.

6. O leitor interessado nesse tipo de contraste entre as narrativas dos pioneiros e o discurso mudancista encontrará material relevante em diversas coletâneas de depoimentos: Goiânia $(1985,1992)$ e Teles (1986). 
7. Dentre os fotógrafos pioneiros de Goiânia, quase todos estrangeiros - Haroutium Berberian (HB), Alois Feichtenberger, Eduardo Bilemjian, Antônio Pereira da Silva (Silva), Pucci, João de Paula Teixeira Filho (Parateca) e Sílvio Berto -, apenas Berto e Haroutium tiveram participação reconhecida no círculo de sociabilidade dos saraus e reuniões de intelectuais. Contudo, tudo indica que o envolvimento de Berto foi maior nos ambientes de sociabilidade, no sentido simmeliano. Ainda que Haroutium estivesse presente em praticamente todos os eventos musicais, sua participação social era limitada. O fotógrafo Jair Mendes, seu auxiliar direto, nos fornece, em entrevista, uma declaração que comprova a afirmação anterior, quando solicitado a caracterizar a freguesia do Foto HB: "Era clientela mais de gente simples, porque ele era muito simples, tinha dificuldade pra conversar, falava um português bem enrolado”.

8. A metáfora do estúdio fotográfico como fábrica de imagens remete ao conceito de “fabricação”, elaborado por Goffman (1984, p. 83): “A fabricação constitui uma segunda modalidade de transformação de atividades, em que há um esforço intencional de manipulação, por um ou mais indivíduos, de forma que pelo menos um dos outros seja induzido a uma falsa crença sobre o que está acontecendo”. A atividade de fotografar em estúdio seria um tipo de “fabricação benigna”, i.e., uma transformação em que não há prejuízo dos interesses das pessoas envolvidas, assim como acontece num treinamento dissimulado em estágios.

9. O termo “reportagem”, utilizado por Berto e outros fotógrafos na época do desenvolvimento inicial de Goiânia, não tem ainda como referência a fotorreportagem, ou o uso da fotografia atrelado à informação ou à comunicação. Trata-se do gênero fotográfico de “reportagem social”, que remonta ao início do século XX. Carlos Malta, primeiro funcionário público com cargo de fotógrafo documentarista no Rio de Janeiro de 1903, utilizava o termo “reportagem social” para se referir ao atendimento a pedidos de famílias ilustres que o solicitavam para registrar festas, casamentos e comemorações, além de fazer retratos (OLIVEIRA JR., 1998, p. 81). Esse era o gênero de fotografia dominado por Berto, tanto no estúdio fixo quanto como fotógrafo itinerante pelo interior de Goiás.

10. Informações mais detalhadas sobre a Revista Oeste podem ser encontradas em Dayrell (1977) e Costa (1994).

11. Almeida Carvalho foi um pintor português que fez uma breve passagem por Goiânia na década de 1940, influenciando, com sua linha acadêmica, alguns pintores da época. Em 1947 participou da IV Exposição de Pintura, Escultura e Arquitetura da Sociedade Pró-Arte de Goiaz (Meneses, Amaury. Da caverna ao museu: dicionário das artes plásticas em Goiás, 1998).

12. O busto de Getúlio Vargas está hoje guardado no Museu Pedro Ludovico; foi esculpido em jacarandá, em 1940, pelo artista Silope.

13. A concepção realista da fotografia, que legitima a foto documental, está evidentemente abalada em nossa época, em que a manipulação eletrônica das imagens se tornou corriqueira. Contudo, a possibilidade de intervir, subjetiva e criativamente, na imagem fotográfica nos remete à pintura. O que fazemos com o Photoshop não difere muito, nesse sentido, com o que fazia Berto ao “maquiar” suas fotografias usando o retoque 
como recurso, embora se trate de processos diferentes de produção de imagens. A análise de Lúcia Santaella (Santaella, 1998; Santaella e Nöth, 1999 [1997]) do processo evolutivo da produção de imagens pode nos auxiliar na compreensão de uma possível convivência entre realismo e nominalismo na concepção da fotografia. Ela admite três paradigmas (num sentido mais metafórico e genérico que o empregado por Kuhn em sua Estrutura das revoluções científicas) na evolução das imagens. O paradigma pré-fotográfico depende da habilidade manual para dar forma ao mundo visível ou invisível e se refere a imagens em pedra, desenho, pintura, gravura e escultura. Solicita a contemplação do receptor. O paradigma fotográfico faz uma conexão física e dinâmica com o que existe no mundo e depende de máquinas capazes de registar objetos; refere-se à fotografia, a filmes, a vídeos e à holografia. Requer a obervação do receptor. O paradigma pós-fotográfico relaciona-se com imagens sintéticas ou infográficas, inteiramente computacionais. As imagens pós-fotográficas solicitam a interação com o receptor. Embora o esquema de Santaella privilegie o momento da produção, isso não impede que analisemos suas conseqüências pragmáticas e semióticas, assim como a possibilidade de articulação entre um paradigma dominante e outros residuais, já que não se requer, como Kuhn, a cristalização e a predominância de um paradigma; afinal, estamos no terreno do uso da fotografia, e não do uso científico da fotografia.

\section{Referências}

Bernardes, Genilda D’Arc Bernardes. Goiânia, cidade planejada/ cidade vivida: discurso e cultura da modernidade. 1998. Tese (Doutorado) - Universidade de Brasília.

Coelho, Maria Beatriz Ramos de Vasconcellos. A construção da imagem da nação brasileira pela fotodocumentação: 1940-1999. 2000. Tese (Doutorado) - FFLCH, Universidade de São Paulo.

Coнn, Gabriel. As diferenças finas: de Simmel a Luhmann. Revista Brasileira de Ciências Sociais. v. 13, n. 38, p. 53-62, out. 1998.

Costa, Maria Beatriz Ribeiro. A revolução de 1930 e a Revista Oeste na consolidação de Goiânia: do bandeirismo utópico à concretização do discurso. 1994. Dissertação (Mestrado) - FCHF, Universidade Federal de Goias.

DAYRELL, Eliane Garcindo. “Oeste”: Ideologia e história. Inter-ação, Goiânia, ano II, n. 4, p. 11-57, 1977.

DuboIs, Philippe. $O$ ato fotográfico e outros ensaios. 3.ed. Tradução de Marina Appenzeller. Campinas: Papirus, 1998 [1990]. 
Eco, Umberto. Semiótica e filosofia da linguagem. Tradução de Mariarosaria Fabris e José Luiz Fiorin. São Paulo: Ática, 1991 [1984].

FERREZ, Gilberto. A fotografia no Brasil: 1840-1900. 2.ed. Rio de Janeiro: Funarte: Fundação Nacional Pró-Memória, 1985.

Flusser, Vilém. Filosofia da caixa preta: ensaios para uma futura filosofia da fotografia. Tradução do autor. São Paulo: Hucitec, 1985 [1983]. Freund, Gisèle. Photographie et société. Paris: Seuil, 1974. [Tradução portuguesa: Fotografia e sociedade. Tradução de Pedro Miguel Frade. Lisboa: Veja, 1989].

GoffmAn, Erving. Frame analysis. New York: Harper, 1974.

GoiÂnia. Prefeitura Municipal. Assessoria Especial de Cultura. Memória cultural: ensaios da história de um povo. Goiânia, 1985.

GoiÂnia. Plano de desenvolvimento integrado de Goiânia. Goiânia: Instituto de Planejamento Urbano (Iplan), 1992. v. 1.

Goíśs. Agência Goiana de Cultura Pedro Ludovico Teixeira. O fotógrafo Sílvio Berto. Cadernos de Fotografia do MIS 2. Goiânia: MIS, 2001. Grangeiro, Cândido Domingues. As artes de um negócio: a febre fotographica - São Paulo 1862-1886. 1993. Dissertação (Mestrado) IFCH, Universidade Estadual de Campinas.

GrangeIRo, Cândido Domingues. As artes de um negócio: no mundo da técnica fotográfica do século XIX. Revista Brasileira de História, v. 18, n. 35, 1998.

LimA, Solange Ferraz de. O circuito social da fotografia: estudo de caso - II. In: FABRIs, Annateresa (Org.). Fotografia: usos e funções no século XIX. 2.ed. São Paulo: Edusp, 1998 [1991]. p. 59-82.

Machado, Arlindo. A ilusão especular: introdução à fotografia. São Paulo: Brasiliense: Funarte, 1984.

Miceli, Sergio. Imagens negociadas. São Paulo: Companhia das Letras, 1996.

OliveIRA, Eliézer Cardoso de. Imagens e mudança cultural em Goiânia. 1999. Dissertação (Mestrado) - Universidade Federal de Goiás.

OliveIRA JR., Antonio Ribeiro de. O visível e o invisível: um fotógrafo e o Rio de Janeiro no início do século XX. In: Samain, Etienne (Org.). $O$ fotográfico. São Paulo: Hucitec, 1998. p. 74-84. 
Peirce, Charles Sanders. Collected papers of Charles Sanders Peirce. v. 2. Editado por Arthur W. Burks. Cambridge: Harvard University, 1958 [1931-1935].

SANTAELlA, Lucia; NöTH, Winfried. Imagem: cognição, semiótica, mídia. 2.ed. São Paulo: Iluminuras, 1999 [1997].

Santaella, Lúcia. Os três paradigmas da imagem. In: Samain, Etienne (Org.). O fotográfico. São Paulo: Hucitec, 1998. p. 303-316.

Schaeffer, Jean-Marie. A imagem precária: sobre o dispositivo fotográfico. Tradução de Eleonora Bottman (Colaboração de Denise Bottman). Campinas: Papirus, 1996 [1987].

SIMMEL, Georg. Sociabilidade: um exemplo de sociologia pura ou formal. O estrangeiro. In: Moraes Filho, Evaristo (Org.). Georg Simmel. Tradução de Dinah de Abreu Azevedo. São Paulo: Ática, 1983. p. 165181, 182-188.

Sonesson, Göran. Pictorial semiotics: the state of the art at the beginning of the nineties. Disponível como artigo on-line: http://www.arthist.lu.se/ kultsem/sonesson/pict sem 1.html, em 27/11/1999.

Teles, José Mendonça (Org.). Memórias goianienses. Goiânia: Editora da Universidade Católica de Goiás, 1986.

SontAG, Susan. Ensaios sobre a fotografia. Tradução de Joaquim Paiva. Rio de Janeiro: Arbor, 1981 [1973].

Zunzunegui díEz, Santos. Pensar la imagen. 2.ed. Madrid: Catedra: Universidad del País Vasco, 1992.

\section{Jornais e revistas}

Diário da Manhã. Goiânia, 13/11/1981 e 13/8/2001.

Folha de Goiás. Goiânia, 3/4/47 e 6/6/1976.

O Popular. Goiânia, 21/3/93.

Revista Oeste. Revista mensal. Edição fac-similar em comemoração ao cinqüentenário da Fundação de Goiânia. Goiânia: UCG/CEF, 1983. 


\section{Entrevistas}

Belkiss Spenzieri, musicista e pedagoga, concedida a Stela Horta Figueiredo em 15 de maio de 2001. Acervo do MIS - Goiânia.

Eleyson Rocha de Oliveira, fotógrafo, auxiliar de Sílvio Berto, concedida a Stela Horta Figueiredo em 13/12/2000. Acervo do MIS - Goiânia.

JAIR MEndes, fotógrafo, auxiliar de Haroutium Berberian, concedida a Stela Horta Figueiredo em 18/11/2000. Acervo do MIS - Goiânia.

Marta dos Santos Berto, esposa de Sílvio Berto, do lar, concedida a Stela Horta Figueiredo em 17/11/2001. Acervo do MIS - Goiânia.

Sílvio Berto, fotógrafo, concedida a Tércia Neiva e Marly Ferreira, em agosto de 1983, para o Projeto Goiânia 50 Anos, do Iplan. Secretaria do Planejamento de Goiânia. Núcleo de Biblioteca e Documentação. 